\title{
A Mixed Approaches Method Used to Investigate Teacher Cognition of English Language Teaching
}

\author{
Nguyen Viet Hung ${ }^{1}$ \\ ${ }^{1}$ Faculty of Postgraduate Studies at University of Languages and International Studies, Vietnam National \\ University, Hanoi, Vietnam \\ Correspondence: Nguyen Viet Hung, PhD Student of ELT Methodology, Faculty of Postgraduate Studies at \\ University of Languages and International Studies, Vietnam National University, Hanoi, Vietnam. Tel: \\ 84-972-862-865/84-904-810-638. E-mail: nguyenviethungvnu@gmail.com
}

Received: May 28, 2012 Accepted: July 10, 2012 Online Published: October 12, 2012

doi:10.5539/elt.v5n11p161 URL: http://dx.doi.org/10.5539/elt.v5n11p161

\begin{abstract}
This paper is a part in a bigger research project related to ELT quality in secondary schools in Vietnam since the implementation of the new series of English textbooks was officially passed by in 2006, and the innovated direction was paid to task-based language teaching (TBLT). The purpose of this paper is to make argumentation on why, what and how to use mixed approaches method to investigate two subdomains of teacher cognition teacher perception and teacher belief. Firstly, an introduction in the research project and research questions about secondary school teacher perception of TBLT and teacher belief of textbooks is shortly made. Secondly, the question what the mixed approaches method are like is dealt with. Next, the question why the mixed approaches method should be used in investigating teacher cognition in general and teacher perception as well as teacher belief in particular is answered and illustrated by writer's framework of research paradigm for the suitability and applicability. Lastly, the question how the mixed approaches method should be implemented to answer the research project questions is clarified and argued for its suitability.
\end{abstract}

Keywords: teacher cognition, teacher belief, teacher perception, paradigm, approach, mixed approaches method

\section{Introduction}

It is widely acknowledged that teachers have their own theoretical beliefs and perceptions about language learning and teaching, and that those tend to shape the teaching practices (Pajares, 1992; Woods, 1996; Hung, 2011). For three fast decades, significant contributions to uncovering the effects of teachers' cognitions to teaching practices have been made widely in both mostly first language (L1) education contexts and foreign language contexts (Borg, 2003, 2006, 2009). According to Borg (2003), teacher belief and teacher perception are terms under a bigger umbrella term - teacher cognition. In spite of the proliferation of studies of this field all over the world, few works have been done in ELT context of Vietnam. Canh (2009) report on 249 in-service secondary school English as a Foreign Language (EFL) teachers' beliefs about new textbooks. Then another project research by Canh (2012) in year of 2009 (and then his work was published in early 2012) has been carried out to seek for the answer about teacher beliefs of grammar teaching in Vietnam. The latest study in this field has just been carried out by Barnard \& Viet (2009) in University of Waikato, New Zealand. His research project's name is "Task-Based Language Teaching: A Vietnamese Case Study Using Narrative Frames to Elicit Teachers Beliefs". In this research, Barnard \& Viet used narrative frames (as suggested by Barkhuizen \& Wette, 2008) to explore what teachers know and believe about the reformed curricular in their specific contexts in comparison with the former curricular in the direction of grounded analysis (as suggested by Charmaz, 2006). He mainly asked teachers to write (in Vietnamese) their reflective comments about their attitudes towards TBLT, and their recent experience of applying it in their classroom. So far, no more study has met the need of teachers' cognition issues in secondary school context. Hence, my study on secondary school teachers' perception of their teaching methods (TBLT) and their beliefs about textbooks is set to answer the need (Hung, 2011).

Before doing any researches, it is crucial to have tools, which refers to a clear framework of research paradigm or a research methodology within which our work will be directed (Maxwell \& Loomis, 2002). The selection of research paradigm depends on numbers of factors, research aims, accordingly research objectives, research types, 
research context, etc. (Creswell, 2003; Maxwell \& Miller, 2008). The research of teacher cognition occurred decades ago with numbers of various approaches of research methods (Landis, 1984; Borg, 2006). Our research project dealing with secondary school teacher perception of TBLT and teacher belief of textbooks with the intention to investigate teachers' cognition (a qualitatively interpretive research domain) in a large area related to a survey policy (a quantitatively descriptive research domain) in judging teaching quality after the new series of English textbooks was used in 2006 may relates to a complicated research paradigm framework (Hung, 2007, 2010, 2011, 2012a, 2012b, 2012c, 2012d). The sections below will in turn discuss every issue.

\section{Research Project Setting}

\subsection{Research Aims and Objectives}

The main aim of the research is to investigate two subdomains of teacher cognition -teacher perception and beliefs (under the viewpoint of Borg, 2003, 2006) in order to propose the proper policy to enhance English language teaching quality in a remote area, the northwest area (NWA). The research lays a great chance for secondary school teachers to raise their voices about what they are facing everyday. The fact can take a corner contribution in evaluating the effectiveness of a series of textbooks after a rather long time it was implemented. Hopefully, this primary research result can be put into consideration of forthcoming syllabus design in a near future when Ministry of Education and Training (MOET) asks for the innovation of textbook of English in a few years coming.

The main aim above is specified into specific and reachable objectives of the research as follows: (1) to find out how teachers conceptualize TBLT, (2) to find out what teachers believe in the series of textbooks, (3) to clarify the factors that shape those types of cognition in the teaching context.

\subsection{Research Questions}

In this descriptive and interpretive study, numbers of research instruments will be used to identify teachers' cognition in teaching method and textbooks. The research questions then sub-objectives/sub-questions central to the study are:

\section{What are the perceptions of secondary school teachers towards task-based language learning?}

1) How do teachers conceptualize task-based learning (TBLT) theoretically?

(The answer for this question is based on the survey questionnaire in a large scale. The statistical data is described and interpreted carefully to find out the characteristics of teachers' perceptions)

2) What shape teachers' perceptions of task-based language teaching?

(The answer for this question is based on the survey questionnaire in combination with the observation of 20 cases' class teaching; correlations between indicators of teachers' perceptions and the factors that construct teachers' perceptions are clarified)

3) To what extent do data of teachers' perception from different instruments match one another?

(The congruence/matches and incongruence/mismatches between theoretical perception and classroom teaching practice is revealed basing on the data triangulation - comparison between the statistical data of the survey questionnaire and the data of class observation sheets as well as the interview data of 20 cases)

2. What are secondary school teachers' beliefs and attitudes in the new secondary school textbooks in the teaching context?

1) How do teachers believe about their textbooks personally?

(The answer for this question is based on the survey questionnaire in a large scale. The statistical data is described and interpreted carefully to find out the characteristics of teachers' beliefs).

2) What shape teachers' beliefs in textbooks?

(The answer for this question that is mainly based on the survey is to find out correlations between indicators of teachers' perceptions and the factors that construct teachers' perceptions are clarified)

3) What are congruence/matches and incongruence/mismatches between their beliefs according to data of teachers' beliefs from different instruments?

(The congruence/matches and incongruence/mismatches between data in the survey questionnaire and the data from the interviews is comparison through data triangulation - comparison between the statistical data of the survey questionnaire in a large scale and the interview data of 20 cases) 


\subsection{Research Context}

With regard to NWA including provinces like Laocai, Yenbai, Sonla, Dienbien, Laichau, Hoabinh cultural values are rich and much different from other areas; economic and educational identities are low and underdeveloped in comparison with other areas; therefore, social and education researches in this area must have different dependability and credibility. According to my firsthand investigation of the teacher number by asking officers in provincial departments of education and training, there is an approximant number of about 1,500 teachers of English working in secondary schools in these six provinces; in which about 800 teachers use this set of textbooks. The compulsory use of these textbooks cannot be made notably because of the fact a lot of lower secondary schools in NWA do not ask their students to learn English as a compulsory subject; teachers in secondary schools that accept students from non-English teaching lower secondary schools, therefore, have to use the former set of textbooks with much lower proficiency and requirements. Besides, teachers in this area are diverse in teaching experience from newly-recruited to senior teachers, in qualification from associate college degree to in-service university degree to regular university degree and higher degree. They have to face with a lot of difficulties in the shortage of living condition, the weakly supported economics, the hard transportation and teaching facilities. In language classes, there are always from 40 to 60 students in each class, which seem to a popular phenomenon in comparison with other provinces. Unlike other provinces, students at NWA have less or no exposure to authentic English because of isolated location of NWA from developed areas, which is not convenient to regional and international interactions, and accordingly reduces the opportunity of acquiring foreign languages.

As far as the teaching of English is concerned, methodological renovation is one of the primary focuses of the provincial department of education and training in an attempt to raise the quality of English language teaching. The implementation of the set of new textbooks from 2006 placed all Vietnamese teachers of English in the rush of teaching renovation; teachers in NWA are no exceptions. As mentioning to the new set of textbooks selected for English teaching in NWA, it - nothing different from what used in other schools in Vietnam - is obviously task-based one basing on the framework of Willis' (Van, 2011, p. 103). This series of textbooks was carefully designed by a group of ELT specialists headed by Prof. Dr. Hoang Van Van, and this was a big effort to change the teachers' attitude, teachers' awareness of English teaching in Vietnam from teacher-centered orientation to learner-centered orientation. However, through casual talks with secondary school teachers and through some minor research assignments from my practicum students in secondary school that they did their teaching practice, surprising information was verbalized, in which teacher-centeredness was admitted to be popular and learner-centeredness was by far reachable although teachers usually led their teaching according to what the course books instruct.

In mentioning to the textbooks, it is a fact that the teaching model adopted in textbooks from grade $10^{\text {th }}$ to grade $12^{\text {th }}$ shapes the framework of each unit with five parts (reading, speaking, listening, writing, language focus), and in each skill part consists of three phases (pre-task, while-task and post-task) each phase of which has smaller or subtasks or activities. To get this framework compared with ancestors' ones, it fits well with the one proposed by Willis $(1996,1998,2007,2009)$. A little deviation is that the task cycle in the new series of textbooks does not accomplish in a class teaching period but in 10 periods ( 2 periods for each part: reading, speaking, listening, writing, language focus), so a task in these textbooks is bigger and more ranging to be afforded than the TBLT framework stated in literature.

This fact really attracted my attention and I formed the research ideas to uncover the mysterious teaching in this area.

\section{Research Paradigm, Approach, Strategies and Framework}

In order to uncover teacher cognition as the aforementioned research questions initiated, a clear research paradigm or theory then the research approach and research methods or strategies must be identified and designed to build a research framework. This section is to clarify these issues.

The choice of a certain methodology and research design informed by researchers' theoretical perspective is commonly referred as research paradigm. The term paradigm derives from the work of the historian of science Thomas Kuhn (1962); it refers to a set of very general philosophical assumptions about the nature of the world (ontology) and how we can understand it (epistemology), assumptions tent to be shared by researchers working in a specific field or tradition. Paradigms also typically include specific methodological strategies linked to these assumptions, and identify particular studies that exemplify these assumptions and methods. In a brief manner, a paradigm can be defined as the "basic belief system or world view that guides the investigation" (Guba \& 
Lincoln, 1994, p. 105). In literature, paradigm is usually equivalent to theory and philosophy, and it is paradigm that directs research approach and then research approach in turns directs chosen methods or strategies.

According to Creswell (2003) there are different approaches or frameworks of designing a proposal and doing a research. He mostly focuses on three approaches "quantitative, qualitative, and mixed methods approaches. The first has been available to the social and human scientist for years, the second has emerged primarily during the last three or four decades, and the lasts is new and still developing in form and substance" (p. 3). Quantitative research, qualitative research and mixed-methods research belongs to different paradigms and research approaches (Creswell, 2003, 2009). Examples of such paradigms relevant to quantitative research are philosophical positions such as positivism, constructivism, realism, and pragmatism, each including very different ideas about reality. Paradigms that are relevant to qualitative research include interpretivism, critical theory, feminism, postmodernism, and phenomenology, and there are even more specific traditions within these (Creswell, 1997, 2003, 2009; Schram, 2005).

In quantitative approach, some common strategies are the true experiments and quasi-experiments and correlation studies (Campbell \& Stanley, 1963), and specific single-subject experiments (Neuman \& Mc McCormick, 1995). More recently, quantitative strategies involved complex experiments with lots of variables and treatments (e.g. factorial designs and repeated measure designs). They also included complicated structural equation models incorporating causal paths and the identification of the collective strength of multiple variables. In qualitative approach, some of the strategies are the narrative method (Clandinin \& Connelly, 2000), phenomenological method (Moustakas, 1994), and grounded theory (Strauss \& Corbin, 1990, 1998; Charmaz, 2006). In the literature about mixed-methods research, there are different perspectives on how research paradigms inform the design of a mixed-methods study; pragmatism paradigm is a case in point. With this paradigm, researchers can collect both quantitative and qualitative data since they develop a rationale for mixing and they can incorporate their data at different stages of the research process. Besides, descriptive paradigm and interpretive paradigm are the two ones in which the former one is choice of collecting and analyzing quantitative data in a single straight approach, and the later one is the deal with collecting and analyzing qualitative data.

The selection of a paradigm, an approach and a method is not a matter of random choice especially in cognition researches. Choosing a paradigm or tradition primarily involves assessing which paradigms best fit with the initial assumptions and methodological preferences (Becker, 1986, pp. 16-17). According to this position, one type of paradigm is best for one type of research, while another paradigm is best when doing another type of research. Kagan (1990) gave out five different approaches to the evaluation of teacher cognition: (a) direct and non-inferential ways of assessing teacher belief, (b) methods that rely on contextual analyses of teachers' descriptive language, (c) taxonomies for assessing self-reflection and metacognition, (d) multimethod evaluations of pedagogical content knowledge and beliefs, and (e) concept mapping (p. 1). Creswell (2003) proposed three types of mixing quantitative and qualitative approaches in investigation of teacher's cognition, i.e., (a) Sequential explanatory procedures, (b) Concurrent procedures, and (c) Transformative procedures (pp. 17-18). For the purpose of my study I chose multiple paradigms which may serve as the foundation for doing mixed-methods research according to transformative procedures which is the hybrid between the sequential explanatory procedures and the concurrent procedures (Creswell, 2003). Holding this view the paradigm that underpins my study is both descriptive and interpretive in which the descriptive data from quantitative method directs and informs the interpretive data from qualitative method. This profiles a framework for topics of interest, methods for collecting data, and outcomes or changes anticipated by the study. Within this framework could be a data collection method that involves a sequential explanatory or a concurrent approach. For the ease of view of research procedure of this project, the researcher designs a visible graphic framework of research paradigm as below. 


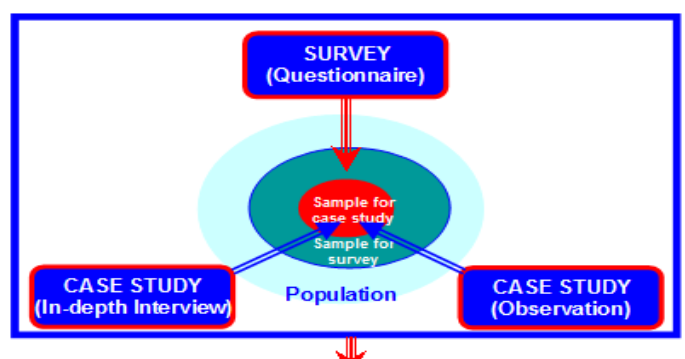

TEACHERS' COGNITION

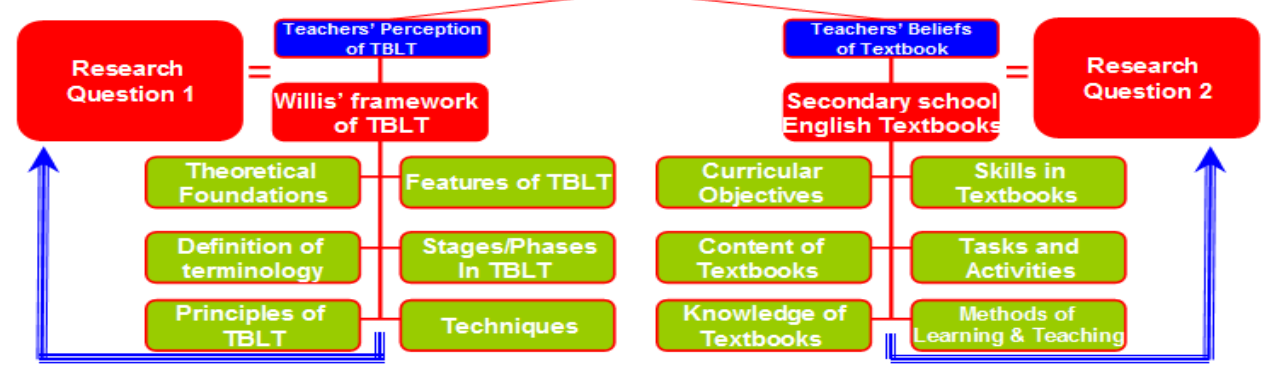

Figure 1. Framework of Mixed Approaches Methods in Investigating Teacher Cognition

In short, from what mentioned above this research of teacher cognition adopts multiple paradigms which direct the mixed approaches and then mixed approaches in turns directs mixed (approaches) methods. In the next discussion, I will make demonstration of what, why, and how the mixed approaches method, wholly or partly, is suitable to research design.

\section{Understanding the Mixed Approaches Method and Research Framework (What)}

This section is to give out the definition of mixed approaches method and the type of mixing, then the description of the research framework as well as the explanation about the nature of survey research method and case studies as components of the set of mixed approaches method.

At the first account, mixed approaches method is usually understood as a procedure for collecting, analyzing, and "mixing" or integrating both quantitative and qualitative data at some stage of the research process in a single study for a better understanding of the research problem (Tashakkori and Teddlie 2003; Creswell 2005). There are about forty mixed-methods research designs reported in the literature (Tashakkori \& Teddlie, 2003). Creswell et al. (2003) identified the six most often used designs, which include three concurrent and three sequential designs.

At the second account, the mixed approaches method, in the figure above, the transformative procedures - the hybrid between the sequential explanatory procedures and the concurrent procedures (Creswell, 2003), is adopted to investigate two subdomains of teacher cognition - teacher perception and teacher belief under the classification of Borg's (2003). The concurrent design enables researcher to converge quantitative and qualitative data in order to provide a comprehensive analysis of the research problem. In this design, the investigator collects both forms of data at the same time; the questionnaire survey for 200 subjects can be coincided with the semi-structured interview for 20 participants. The sequential explanatory design, is highly popular among researchers and implies collecting and analyzing first quantitative and then qualitative data in two consecutive phases within one study. Its characteristics are well described in the literature (Tashakkori \& Teddlie, 1998; Creswell, 2003, 2005; Creswell et al., 2003). In this study, the unstructured interviews and observation are done at the second phase in time, after the quantitative survey questionnaire and semi-structured interviews; and then integrates the information in the interpretation of the overall results.

To go back to the framework, the upper rectangle indicates the way of mixing methods into one. The research starts with a cross-sectional questionnaire survey that is carried out in a large scale within 200 subjects chosen randomly from a big population of about 1,500 teachers (the red arrow focuses on the second circle) as the population (the outer circle). This is the main information channel for data collection as no other ways can be better in collecting data in a so large area like NWA. At the same time, with the semi-structured interview for 20 
participants as case studies is made to get qualitative text data (this is called $1^{\text {st }}$ time Interview). After the survey, information is analysed and quantified into different categories of numerical coded data by SPSS software, version 16.0, which closes the phase of quantitative approach research. The next phase is qualitative one with case studies in which about 20 participants are randomly chosen from 6 provinces for and unstructured in depth interviews (this is called $2^{\text {nd }}$ time Interview) and then class observations. The qualitative data will release deeper understandings of teacher cognition emerged in the preliminary survey research in that it explains why such a statistical number occur. This is in fact one way of triangulate research data (Creswell, 2003, 2009). The lower part of the framework is description of the category of teacher cognition domain. The red arrow indicates that the mixed approaches method is used as the research tool to act on the research objects - teacher cognition. Having the information for all subdomains by all strategies prescribed above means that two research questions are answered.

Next, I mention about the nature of survey research method in which cross-sectional questionnaire is done in a large scale to find out points of teacher's cognition. Survey research can be understood in the common way from Best (1970). He considered survey research is one in many educational descriptive research methods, that is, they set out to describe the reality, and subdivide this research method into three types, i.e., written survey, oral survey, electronic survey. Descriptive research, according to Best, is concerned with: conditions or relationships that exist; practices that prevail; beliefs, points of views, or attitudes that are held; processes that are going on; effects that are being felt; or trends that are developing. At times, descriptive research is concerned with how what is or what exists is related to some preceding event that has influenced or affected a present condition or event (p. 12). Survey research is subdivided into 3 types, i.e., written survey, oral survey, electronic survey.

Lastly, the nature of case study is understood by researchers in some common ways. As Aldeman et. al. (1980) in Cohen, Manion \& Morrison (2007) states, 'case study data has been seen as 'strong in reality'. Case studies allow generalizations about and from a singular to a class. Their peculiar strength lies in their attention to the subtlety and complexity of the case in its own right (p. 181). Cohen, Manion \& Morrison (2007) claims: the case study researcher typically observes the characteristics of an individual unit. The purpose of such observation is to probe deeply and to analyse intensively the multifarious phenomena that constitute the life cycle of the unit with a view to establishing generalizations about the wider population to which that unit belongs (p. 181). In cases studies by using interviews and observation, I intent to use "Cumulative Case Studies" as suggested by Cohen, Manion \& Morrison (2007). This research type is to aggregate information from several sites collected at different times. The idea behind these studies is the collection of past studies will allow for greater generalization without additional cost or time being expended on new, possibly repetitive studies.

\section{Reasons for Application of Mixed Approaches Method to Investigate Teacher Cognition of TBLT and the Textbooks (Why)}

The rationale for mixing both quantitative and qualitative data within one study is descended from the fact that neither quantitative nor qualitative methods are sufficient, by themselves, to capture the trends and details of a situation. Therefore, in this section, I will argue for the suitability of chosen research framework both with the combination called mixed approaches method and with each isolated method.

At the first consideration, mixed approaches observations and interviews (qualitative data) are combined with traditional questionnaire surveys (quantitative data) with the hope of reducing limitations of approaches and methods if they are used alone; the biases inherent in any single method can neutralize the biases of other methods. Alternatively, one method can be mediated within another method to provide insight into different levels or units of analysis (Tashakkori and Teddlie, 1998). When used in combination, quantitative and qualitative methods complement each other and allow for a more powerful analysis, taking advantage of the strengths of each (Green, Caracelli, and Graham 1989; Miles \& Huberman, 1994; Tashakkori and Teddlie 1998). I believe that teacher cognition is the big collection of hidden traits that influenced by culture, emotions, values, ethics and learning and teaching experience. Therefore, teachers' cognition can best be understood when triangulated by data collected from different actions in their context. The quantitative statistics from survey research cannot be enough to uncover the teacher perceptions and beliefs as its large-scale information can only be the surface of the iceberg. Besides, teachers' cognition refers closely to the characteristics of the interpretive paradigm of research according to which: humans actively construct their own meanings of situations; meaning arises out of social situations and it is handled through interpretive processes; behaviour and, thereby, data are socially situated, context-related, context-dependent and context-rich (Cohen, Manion \& Morrison, 2004, p. 137). Triangulating data sources is a means for seeking convergence a cross qualitative and quantitative methods (Creswell, 1998, 2002, 2003). From the original concept of triangulation emerged additional reasons for mixing different types of data. For example, the results form one method can help develop or inform the other method 
(Green, Caracelli \& Graham, 1989). These reasons for mixing methods have led writers from around the world to develop procedures for mixed methods strategies of inquiry and to take he numerous terms found in the literature, such as multimethod, convergence, integrated, and combine (Creswell, 1994) and shape procedures for research (Tashakkori \& Teddlie, 2003).

At the second consideration, the reasons of using survey as one method in the mixed one at the first quantitative phase are because of the advantages of this method. In a large scale, the data collected by probability sampling will tend to lead to generalizability so that inferences can be made about some characteristic, attitude, or behavior of this population (Babbie, 1990). Moreover, using survey questionnaire, it is economical to have answers from a huge population by small group of individuals. Besides, it is rapid to have turnaround in data collection (Babbie, 1990). In surveys, the researcher is usually an outsider; it can be somewhat less biased. Further, except for what have mentioned, Morrison (1993: 38-40) claims some other benefits of survey:

- provides descriptive, inferential and explanatory information;

- manipulates key factors and variables to derive frequencies (e.g. the numbers registering a particular opinion or test score);

- gathers standardized information (i.e. using the same instruments and questions for all participants);

- ascertains correlations (e.g. to find out if there is any relationship between gender and scores);

- presents material which is uncluttered by specific contextual factors;

- captures data from multiple choice, closed questions, test scores or observation schedules;

- supports or refutes hypotheses about the target population;

- generates accurate instruments through their piloting and revision;

- gathers data which can be processed statistically;

The last consideration is focused on the reasons for using case studies as the second type in the mixed system at the second qualitative phase, in which the suitability of two instruments (observation and interview) used in case studies are also mentioned. Cohen, Manion \& Morrison (2007: 181) suggest that the case study approach is particularly valuable when the researcher has little control over events. They consider that a case study has several hallmarks:

- It is concerned with a rich and vivid description of events relevant to the case.

- It provides a chronological narrative of events relevant to the case.

- It blends a description of events with the analysis of them.

- It focuses on individual actors or groups of actors, and seeks to understand their perceptions of events.

- It highlights specific events that are relevant to the case.

- The researcher is integrally involved in the case.

- An attempt is made to portray the richness of the case in writing up the report.

Bailey (1978) in Cohen, Manion \& Morrison (2007) identifies some inherent advantages in the participant observation approach used in case study:

- Observation studies are superior to experiments and surveys when data are being collected on non-verbal behaviour.

- In observation studies, investigators are able to discern ongoing behaviour as it occurs and are able to make appropriate notes about its salient features.

- Because case study observations take place over an extended period of time, researchers can develop more intimate and informal relationships with those they are observing, generally in more natural environments than those in which experiments and surveys are conducted.

- Case study observations are less reactive than other types of data-gathering methods. For example, in laboratory-based experiments and in surveys that depend upon verbal responses to structured questions, bias can be introduced in the very data that researchers are attempting to study.

(p. 187)

The interview may bear some typical advantages for the fitness of using in case studies. First, it may be used as the principal means to gather information having direct bearing on the research objectives. Second, according to 
Tuckman (1972), interview can help explore "what is inside a person's head" as it is possible to measure what a person knows (knowledge or information), what a person likes or dislikes (values and preferences), and what a person thinks (attitudes and beliefs). Third, it is very useful to test hypotheses in general and to triangulate text qualitative data with numerical quantitative data in a mixed approaches method model like this research as it works as an explanatory device to help identify variables and relationships with a situation or problem. Interview, in fact, can validate other methods, and help us to go deeper into the respondents' answers of the preliminary survey questionnaire and their reasons for responding as they do.

\section{Procedures of Implementing the Research Framework in Study (How)}

\subsection{Quantitative Phase}

The goal of the quantitative phase is to identify the potential predictive power of selected variables on teachers' perception of TBLT and teachers' beliefs of textbooks. Quantitative data are collected by a cross-sectional survey questionnaire (Creswell, 2005), using a self-developed and pilot tested instrument. The core survey items about teacher's perception of TBLT are based on five-point Likert type scales (Likert, 1932) and reflected the following six variables, representing a range of internal and external to the perception components or factors: (1) teachers' understandings of philosophies directed to TBLT, (2) teachers' understandings of definitions of task and TBLT, (3) teachers' understandings of principles of TBLT, (4) teachers' understandings of features of TBLT, (5) teachers' understandings of stages of TBLT according to Willis' model, (6) teachers' understandings of techniques of TBLT. I identified those factors through the analysis of the related literature. Additionally, the core survey items about teacher's belief of textbooks also based on five-point Likert type scales reflect the following six variables, components or factors: (1) teachers' beliefs of the textbook objectives, (2) teachers' beliefs of the content of the textbooks, (3) teachers' beliefs of the knowledge of the textbooks, (4) teachers' beliefs of the skills in the textbooks, (5) teachers' beliefs of the efficiency of tasks and activities of the textbooks, (6) teachers' beliefs of the suitability of the teaching method of textbooks (TBLT).

The participants selected for the quantitative phase are based on the following stratum probability criteria: (1) being teachers of English in NWA; (2) focusing on first degree of English language teaching (regular bachelor degree, in-service bachelor degree, associate bachelor degree); (3) focusing on years of teaching experience (one to five years, six to ten years, eleven to fifteen years, sixteen to twenty years, more than twenty years); (4) focusing on the ethnic group; (5) focusing on the teacher's economic condition; (6) focusing on the locality of teaching (urban area, rural area, mountainous remote area, mountainous isolated area). A total of 200 teachers met those criteria. Overall, participants responded to the survey is counted at a specific response rate. In analysis process, both univariate and multivariate statistical procedures to analyze the survey data are employed. Cross-tabulation and frequency counts help to analyze the survey demographic information and the participants' answers to separate items on each of the five survey scales. The discriminant function analysis is used to identify the predictive power of six selected factors of each survey part (teacher's perception and teacher's belief). The typical participants are between 25 and 54 years of age, predominantly women, employed full-time, mostly married with children. The descriptive analysis of the survey scale items will show some typical descriptive and inferential data about teacher's perception of TBLT and teacher's belief of the textbooks.

In order to guarantee the reliability and validity of the survey, the survey scale items are established based on pilot and principle survey administration that uses frequency distributions, internal consistency reliability indexes, internal item correlations, and factor analysis before this instrument is officially used.

\subsection{Qualitative Phase}

In the second qualitative phase, I intend to use a multiple case study approach (Yin, 2003) to help explain why certain external and internal factors, tested in the first phase, are significant or not significant predictors of teacher's perception and teacher's belief. A case study is an exploration of a bounded system or a case over time through detailed, in-depth data collection involving multiple sources of information and rich in context (Merriam, 1998). A multiple case study design includes more than one case, and the analysis is performed at two levels: within each case and across the cases (Stake, 1995; Yin, 2003).

For this phase, I purposefully select twenty participants, three to four from each province, from those who have completed the survey questionnaire and be volunteer for sharing thoughts and experience. To provide the richness and the depth of the case description (Stake, 1995; Creswell, 1998), I use multiple sources for collecting the data: (1) in-depth semi-structured interviews with twenty participants to compare the answers between this semi-structured interviews with information on the survey questionnaire; (2) researcher's reflection checklists on each participant's class teaching recorded immediately after the observation; (3) follow-up in-depth unstructured interviews with each participant to secure additional information on the emerging themes or factors from both 
the first survey questionnaire and the observation; (4) academic transcripts and students' files to validate the information obtained during the interviews and to get additional details related to the cases.

I intend to audiotape and transcribe each interview (Creswell, 2005). We conducted a thematic analysis of the text data at two levels, within each case and across the cases, using NVIVO qualitative software for data storage, coding, and theme development. The verification procedures included triangulating different sources of information, member checking, intercoder agreement, rich and thick descriptions of the cases, reviewing and resolving disconfirming evidence, and academic adviser's auditing (Denzin \& Lincoln, 1994; Miles \& Huberman, 1994; Stake, 1995; Creswell, 1998; Creswell \& Miller, 2002).

Themes related to the participants' teacher's perception and teacher's belief will emerge in the analysis of each case and across cases. Despite being common for all participants, those themes may differ in the number of and similarity of subthemes and categories comprising them. Analysis of the number of sentences per each theme across the twenty cases, using the matrix feature, shows the priority of the discussed themes for the participants.

The credibility of this qualitative case study deals with the question of how data are categorised and how the similarities within differences between categories are judged. This can be achieved through first consent letters and then an interacting process that is to seek agreement from experienced researchers and participants. This process may be not fully employed in this study for practical reasons. However, I will show the participants all the transcripts of the interviews, classroom observations and other related notes for confirmability (Janesick, 2000).

\section{Conclusion}

In this paper, I present and argue for the methodology of the research project from the choice of paradigm, to approach and then specific research model. This is one in numbers of possible frameworks; however, it proves to be the most suitable one for my research because of advantages: the combination of research paradigm, approaches and method have been employed and fashioned for years in investigating complicated research issues; the quantitative method as survey can only show statistical numbers and some inferential numerical data without giving out any senses of the fact as those data cannot answer the question why such a thing has occurred; qualitative methods (case study) present in the study as the most proper way to fill the gap as it can give out a deeper understanding of the fact by rich text data as explanations; the strengths of each method belonging to two different approaches (quantitative and qualitative) really work in this study and eliminate the disadvantages of each one. Hopefully, later attentions to this research model for similar projects are paid by researchers.

\section{References}

Adelman, C., D. Jenkins, \& S. Kemmis. (1980). Rethinking case study: notes from the second Cambridge conference. In H. Simons (Ed.), Towards a Science of the Singular (pp. 45-61). Center for Applied Research in Education, University of East Anglia.

Babbie, E. (1990). Survey research methods ( $2^{\text {nd }}$ Ed.). Belmont, CA: Wadsworth Publishing.

Barkhuizen, G., \& Wette, R. (2008). Narrative frames for investigating the experiences of language teachers. System, 36(3), 372-387. http://dx.doi.org/10.1016/j.system.2008.02.002

Barnard, R., \& Viet, N. G. (2010). Task-Based Language Teaching (TBLT): A Vietnamese Case Study Using Narrative Frames to Elicit Teachers' Beliefs. Language Education in Asia, 1(1), 77-86. http://dx.doi.org/10.5746/LEiA/10/V1/A07/Barnard_Nguyen

Becker, H. S. (1986). Writing for social scientists: How to start and finish your thesis, book, or article. Chicago: University of Chicago Press.

Becker, H. S. (1991). Generalizing from case studies. In E. W. Eisner, \& A. Peshkin (Eds.), Qualitative inquiry in education: The continuing debate (pp. 233-242). New York: Teachers College Press.

Best, J. W. (1970). Research in Education. Englewood Cliffs, NJ: Prentice-Hall.

Borg, S. (2003). Teacher cognition in language teaching: a review of research on what language teachers think, know, believe, and do. Language Teaching, 36(2), 81-109. http://dx.doi.org/10.1017/S0261444803001903

Borg, S. (2006). Teacher cognition and language education: Research and practice. London: Continuum.

Borg, S. (2009). Introducing language teacher cognition. Retrieved April 13, 2010 from http://www.education.leeds.ac.uk/people/staff.php?staff $=29$

Campbell, D. T., \& Stanley, J. (1963). Experimental and quasi-experimental designs for research on teaching. In N. Gage (Ed.), Handbook of Research on Teaching (pp. 171-246). Chicago: Rand McNally. 
Canh, L. V., \& Barnard, R. (2009). Curricular innovation behind the closed classroom doors: A Vietnamese case study. Prospect: An Australian Journal of TESOL, 24(2), 20-33.

Canh. L. V. (2012). Form-Focused Instruction: A case Study of Teachers' Belief and Practices. Lap Lambert Academic Publishing GmbH \& Co.KG.

Clandinin, D. J., \& Connelly, F. M. (2000). Narrative inquiry: Experience and story in qualitative research. San Francisco: Jossey-Bass.

Charmaz, K. (2006). Constructing grounded theory: A practical guide through qualitative analysis. Thousand Oaks, CA: Sage.

Cohen, L., Manion, L., Morrison, K. (2004). Research Methods in Education (5 ${ }^{\text {th }}$ Ed.). London, New York: Routledge.

Cohen, L., Manion, L., \& Morrison, K. (2007). Research methods in education (6 ${ }^{\text {th }}$ Ed.). London, New York: Routledge. http://dx.doi.org/10.3108/beej.10.r1

Creswell, J. W. (1994). Research design qualitative and quantitative approaches. Thousand Oaks, CA; SAGE.

Creswell, J. W. (1997). Qualitative Inquiry and Research Design: Choosing among the Five Traditions. Thousand Oaks, CA: Sage.

Creswell, J. W. (1998). Qualitative Inquiry and Research Design: Choosing among the Five Traditions ( $2^{\text {nd }}$ Ed.). Thousand Oaks, CA: Sage.

Creswell, J. W. (2003). Research Design. London, UK: Sage Publish House.

Creswell, J. W. (2005). Educational research: Planning, conducting, and evaluating quantitative and qualitative research $\left(2^{\text {nd }}\right.$ Ed.). Upper Saddle River, NJ: Pearson Education.

Creswell, J. W. (2008). Educational research: Planning, conducting, and evaluating quantitative and qualitative research (3 ed.). Upper Saddle River, NJ: Pearson Prentice Hall.

Creswell, J. W. (2009). Research design: Qualitative, quantitative, and mixed methods approaches (3rd Edition ed.). Thousand Oaks, CA: Sage.

Creswell, J. W., \& Miller, D. (2002). Determining validity in qualitative inquiry. Theory into Practice, 39(3), 124-30.

Creswell, J. W., Clark, V. L. P., Gutmann, M., \& Hanson, W. (2003). Advanced mixed methods research designs. In A. Tashakkori, \& C. Teddlie (Eds.), Handbook on mixed methods in the behavioral and social sciences (pp. 209-240). Thousand Oaks, CA: Sage.

Denzin, N. K., \& Lincoln, Y. S. (eds). (1994). Handbook of Qualitative Research. Thousand Oaks, California: Sage Publications Inc.

Ellis, R. (2003). Task-based language teaching and learning. Oxford, England: Oxford University Press.

Geertz, C. (1973). The interpretation of cultures. New York: Basic Books.

Greene, J. C., Caracelli, V. J., \& Graham, W. F. (1989). Toward a conceptual framework for mixed-method evaluation designs. Educational Evaluation and Policy Analysis, 11(3), 255-274. http://dx.doi.org/10.2307/1163620

Guba, E. G., \& Lincoln, Y. S. (1994). Competing paradigms in qualitative research. In N. K. Denzin, \& Y. S. Lincoln (Eds.), Handbook of qualitative research (pp. 105-117). Thousand Oaks, CA: Sage.

Hung, N. V. (2007). Task-Based Language Teaching: An approach to Enhance Student's Motivation of English Learning. Vietnamese Linguistics for Young Researchers, 12, 224-228.

Hung, N. V. (2010). Task-Based Language Teaching: Some theoretical issues. Vietnam National Linguistics 2010, $15,212-217$.

Hung, N. V. (2011). Why should we investigate secondary school teacher beliefs and teacher perceptions of English Language Teaching? VNU Journal of Science: Foreign Languages, 27(2), 124-131.

Hung, N. V. (2012a). Application of Task-based Language Teaching: Solution for large and multi-level language classes. Vietnam National Linguistics 2011, 16, 361-371.

Hung, N. V. (2012b). Mother Tongue Use in Task-Based Language Teaching Model. English Language Teaching (Canada), 5(8), 23-30. http://dx.doi.org/10.5539/elt.v5n8p23 
Hung, N. V. (2012c). Some theoretical issues in teacher's cognition. TNU Journal of Science and Technology, 94(6), 97-103.

Hung, N. V. (2012d). Strategic Interaction: An approach of Application Task-Based Language Teaching Model of Willis. Journal of Science of HNUE, 57(5), 125-136.

Janesick, V. (2000). The Choreography of Qualitative Research Design: Minuets, Improvisations, and Crystallization. In N. K. Denzin, \& Y. S. Lincoln (Eds.), The Handbook of Qualitative Research (pp. 379-400). Thousand Oaks: California, Sage Pub.

Kagan, D. (1990). Ways of evaluating teacher cognition: inferences concerning the Goldilocks principle. Review of Educational Research, 60(3), 419-69. http://dx.doi.org/10.2307/1170760

Kuhn, T. S. (1962). The structure of scientific revolutions. Chicago, IL: University of Chicago Press.

Likert, R. (1932). A Technique for the Measurement of Attitudes. New York, USA: ColumbiaUniversity Press.

Landis, C. (1984). Teachers' Decision Factors in Judging and Planning Discussion Activities for Elementary Art Programs. Marilyn Zurmuehlen Working Papers in Art Education, 3(1), Article 28, 86-90.

Maxwell, J. A., \& Loomis, D. (2002). Mixed method design: An alternative approach. In A. Tashakkori, \& C. Teddlie (Eds.), Handbook of mixed methods in social and behavioral research (pp. 241-271). Thousand Oaks, CA: Sage.

Maxwell, J. A., \& Miller, B. A. (2008). Categorizing and connecting strategies in qualitative data analysis. In P. Leavy, \& S. Hesse-Biber (Eds.), Handbook of emergent methods (pp. 461-477). New York, USA: Guilford Press.

Merriam, S. B. (1988). Case Study Research in Education. San Francisco, CA: Jossey Bass.

Miles, M., \& Huberman, M. (1994). Qualitative Data Analysis ( $2^{\text {nd }}$ Ed.). Beverly Hills, CA: Sage.

Morrison, K. R. B. (1993). Planning and Accomplishing School-Centred Evaluation. Dereham, UK: Peter Francis.

Moustakas, C. (1994). Phenomenological research methods. Thousand Oaks, CA: Sage.

Neuman, S. B., \& McCormick, S. (1995). Single-subject experimental research: Application for literacy. Newark, DE: International Reading Association.

Pajares, M. F. (1992). Teachers' beliefs and educational research: cleaning up a messy construct. Review of Educational Research, 62(3), 307-332. http://dx.doi.org/10.3102/00346543062003307

Schram, T. H. (2005). Conceptualizing and proposing qualitative research. Upper Saddle River, NJ: Merrill Prentice Hall.

Stake, R. E. (1994). Case studies. In N. K. Denzin, \& Y. S. Lincoln (eds), Handbook of Qualitative Research (pp. 236-47). London: Sage Publications.

Stake, R. E. (1995). The art of case study research. Thousand Oaks, CA: Sage.

Strauss, A., \& Corbin, J. (1990). Basics of Qualitative Research: Grounded Theory Procedures and Techniques. Newbury Park, CA: Sage.

Strauss, A. L., \& Corbin, J. (1994). Grounded theory methodology: an overview. In N. Denzin, \& Y. Lincoln (Eds.), Handbook of Qualitative Research (pp. 273-85). Thousand Oaks, CA: Sage.

Tashakkori, A., \& Teddlie, C. (1998). Mixed methodology: Combining qualitative and quantitative approaches. Applied Social Research Methods Series, 46. Thousand Oaks, CA: Sage.

Tashakkori, A., \& Teddlie, C. (2003). Major issues and controversies in the use of mixed methods in the social and behavioral sciences. In A. Tashakkori, \& C. Teddlie (Eds.), Handbook on mixed methods in the behavioral and social sciences (pp. 3-50). Thousand Oaks, CA: Sage.

Tuckman, B. W. (1972). Conducting Educational Research. New York: Harcourt Brace Jovanovich.

Van, H. V. (2011). English curriculum and textbook - standard category - for upper secondary school in Vietnam. VNU Journal of Science: Foreign Languages, 27(2), 96-106.

Willis, J. (1996). A Framework for Task-Based Learning. Harlow, Essex: Addison Wesley Longman. Longman.

Willis, J. (1998). Task-based learning? What kind of adventure? Retrieved July 12, 2007 from http://langue.hyper.chubu.ac/jp/jalt/pub/ttt/98/jul/willis.html 
Willis, D., \& Willis, J. (2007). Doing Task-based Teaching. Oxford: Oxford University Press.

Willis, D., \& Willis, J. (2009). Task-based language teaching: some questions and answers. The Language Teacher, 33(3), 3-8.

Woods, D. (1996). Teacher Cognition in Language Teaching. Cambridge: Cambridge University Press.

Yin, R. K. (2003). Case Study Research: Design and Methods ( $3^{\text {rd }}$ Ed.). London, UK: Sage.

\section{Author}

Nguyen Viet Hung is a doctoral student in the Faculty of Postgraduate Studies at University of Languages and International Studies - Vietnam National University, Hanoi. He firstly taught English for Taybac University (Northwest University - a university located in a remote mountainous area in the northwest of Vietnam), then he moved to University of Languages and International Studies - Vietnam National University, Hanoi. He has taught in various universities in Vietnam, such as, Hanoi Open University, Hanoi National University of Education, Thang Long University. His interested teaching and research fields are ELT methodology, second language acquisition, teacher cognition and English pronunciation.

\section{Acknowledgments}

I would like to send my acknowledgement to Prof. Dr. Nguyen Hoa, Prof. Dr. Hoang Van Van, Associate Prof. Dr. Le Hung Tien and Dr. Le Van Canh at University of Languages and International Studies - Vietnam National University, Hanoi for their help and encouragements in my study.

\section{Notes}

1. The series of new textbooks of English for secondary schools passed by Ministry of Education and Training (MOET) and officially implemented in 2006 in the direction of both language teaching method and curriculum innovation adopted task-based syllabus design, CLT and TBLT and learner-centeredness approach. Nevertheless, from that time when series of new textbooks of English was in use, few researches have been done to investigate how teachers apply TBLT in their classrooms. The author has carried out a research project on investigating secondary school teachers' beliefs and perceptions of teaching method - TBLT and the new textbooks.

\section{Appendices}

\section{Appendix A: Survey Questionnaire}

\section{Purpose:}

The purpose of this survey is to identify teachers' perceptions of task-based language teaching method, textbooks in Northwest Area (NWA). All secondary school teachers will have the opportunity to participate and consult with ideas.

- Thoughtful and honest answers are important.

- No answers are "right" or "wrong".

- Your participation is voluntary.

- There will be no penalty for not participating in this survey.

\section{Time Required:}

Thank you for your valuable time and insights! This survey includes three sections of Background information, Teacher's perceptions of TBLT and Teachers' beliefs of textbook. In each section, the format is unanimous. It is expected that you (participants) will complete this survey within 30 minutes.

\section{Informed Consent:}

There are minimal cautions to your participation in this study. After you complete this survey it will be assigned a unique identification number and your name will then be removed from the survey.

- You must be 18 years of age or older to participate in this study.

- Your name will not be used during or after the research.

- Any personal information you provide will remain confidential and known only to the researcher.

- Your answers will be used only for the purposes of this study.

- If you have questions regarding this study you may contact Nguyen Viet Hung (0972862865)

- If you have questions regarding your rights as a participant in research projects, you may contact Prof. Dr. 
Hoang Van Van, Chairman of the Postgraduate Faculty, Vietnam National University, Hanoi. No 144, Xuan Thuy Road, Cau Giay District, Hanoi, Vietnam,

URL: http://www.vnu.edu.vn, Email: sdh@vnu.edu.vn/vanhv@vnu.edu.vn

ĐT: 0946296999

Name (please print)

School - Distict - Province

Phone: Email:

We appreciate your participation!

We value your opinions!

Your responses will help make a difference!

\section{SECTION 1: Background Information.}

Please answer the following questions by marking an underlying/circle choice in all the appropriate option that best fit your answers. N/A stands for Not Applicable.

1). How old are you?

(please specify)

2). What is your gender?
A. Male
B. Female

3a). Which province are you working and living?

3b). Which locality does your place belong to, urban area, rural area, mountainous area, mountainous isolated area?

(please specify)

4). What ethnic group are you?

(please specify)

5). What is your economic state?
A. Very poor
B. Poor
C. Average
D. good E. rich

6a). Do you speak any languages other than English?
A. Yes
B. No

6b). If yes, which languages?
N/A Thai
H'Mong
French Russian
Chinese/Japanese

Other (please specify)

7a). The first degree of English language teaching you got before doing your teaching is
A. Regular university degree
B. In-service university degree
C. Associate college degree
Yes, Other (please specify)

7b). Please specify the name of the university which you graduated from

7c). Please specify the graduation rank
A. Pass
B. Strong Pass
C. Credit
D. Good Credit
E. Excellent Credit

8a). After graduating from university, have you ever done another job before your teaching?
A. No
B. Yes

$8 b)$. If Yes, (please specify)

8c). At the present time, are you doing another part-time job except for teaching?
A. No
B. Yes 
8d). If Yes, (please specify)

9a). After getting your first degree, have you ever done a higher course to get a higher degree?
A. No
B. Yes

9b). If Yes, (please specify)

10. Which year did you start your teaching?

(please specify)

11a). Before teaching this set of textbooks, have you ever participated in any workshops of foreign language teaching?
A. No
B. Yes,

11b). If yes, please specify the places and times of your attention.

(places)

(times)

12a). Are you willing to participate in an oral interview?
A. No
B. Yes

12b). If so, please write down your favourite way of interview: face-to-face interview, telephone interview (if yes, please write your number) or online interview (if yes, please write your Skype or Yahoo ID):

Thank you very much for your co-operation in filling in this questionnaire! If you wish to add any other comments please do so below:

\section{SECTION 2: Teachers' Perceptions of TBLT}

Please state your thought with each indicator/statement below according to five point Likert Scale from the lowest agreement extreme (Strongly disagree) to the highest agreement extreme (Strongly agree):

Strongly disagree Disagree Neutral/Slightly agree Agree Strongly agree

\begin{tabular}{|l|l|l|l|l|}
\hline $\mathbf{1}$ & $\mathbf{2}$ & $\mathbf{3}$ & $\mathbf{4}$ & $\mathbf{5}$ \\
\hline
\end{tabular}

\section{Survey Questionnaire of Teachers' Perception of TBLT according to Willis' model $(\mathrm{N}=)$}

\begin{tabular}{|c|c|c|c|c|c|c|}
\hline \multirow{2}{*}{ No } & \multirow{2}{*}{ Indicators/Statements } & \multicolumn{5}{|c|}{ Scale } \\
\hline & & 1 & 2 & 3 & 4 & 5 \\
\hline & Teachers' Understandings of Philosophies directed to TBLT & & & & & \\
\hline 1 & $\begin{array}{l}\text { I know for sure that main the teaching instruction model of implementing the textbooks is } \\
\text { TBLT }\end{array}$ & & & & & \\
\hline 2 & TBLT partly rooted in Psychological Behaviorist Theory & & & & & \\
\hline 3 & TBLT partly rooted in Psychological Cognitive Theory & & & & & \\
\hline 4 & TBLT partly rooted in Natural Approach Theory & & & & & \\
\hline 5 & TBLT partly rooted in Linguistic Functional view of Constructivism Theory & & & & & \\
\hline 6 & TBLT partly rooted in Linguistic Interactional view of Social Constructivism Theory & & & & & \\
\hline 7 & TBLT partly rooted in Educational Heuristic Theory & & & & & \\
\hline \multirow[t]{2}{*}{8} & TBLT partly rooted in Educational Learner-Centered Instructional Approach & & & & & \\
\hline & Teachers' Understandings of Definitions of Task and TBLT & & & & & \\
\hline 9 & A task is directed to communicative goals. & & & & & \\
\hline 10 & A task involves a primary focus on meaning. & & & & & \\
\hline 11 & A task has a clearly defined outcome. & & & & & \\
\hline 12 & A task is any activity in which the target language is used by the learner. & & & & & \\
\hline 13 & $\begin{array}{l}\text { Task is a language learning activity which is designed by teachers to enable students' } \\
\text { communicative ability in target language. Tasks have goals, outcome, procedure and } \\
\text { completion }\end{array}$ & & & & & \\
\hline
\end{tabular}




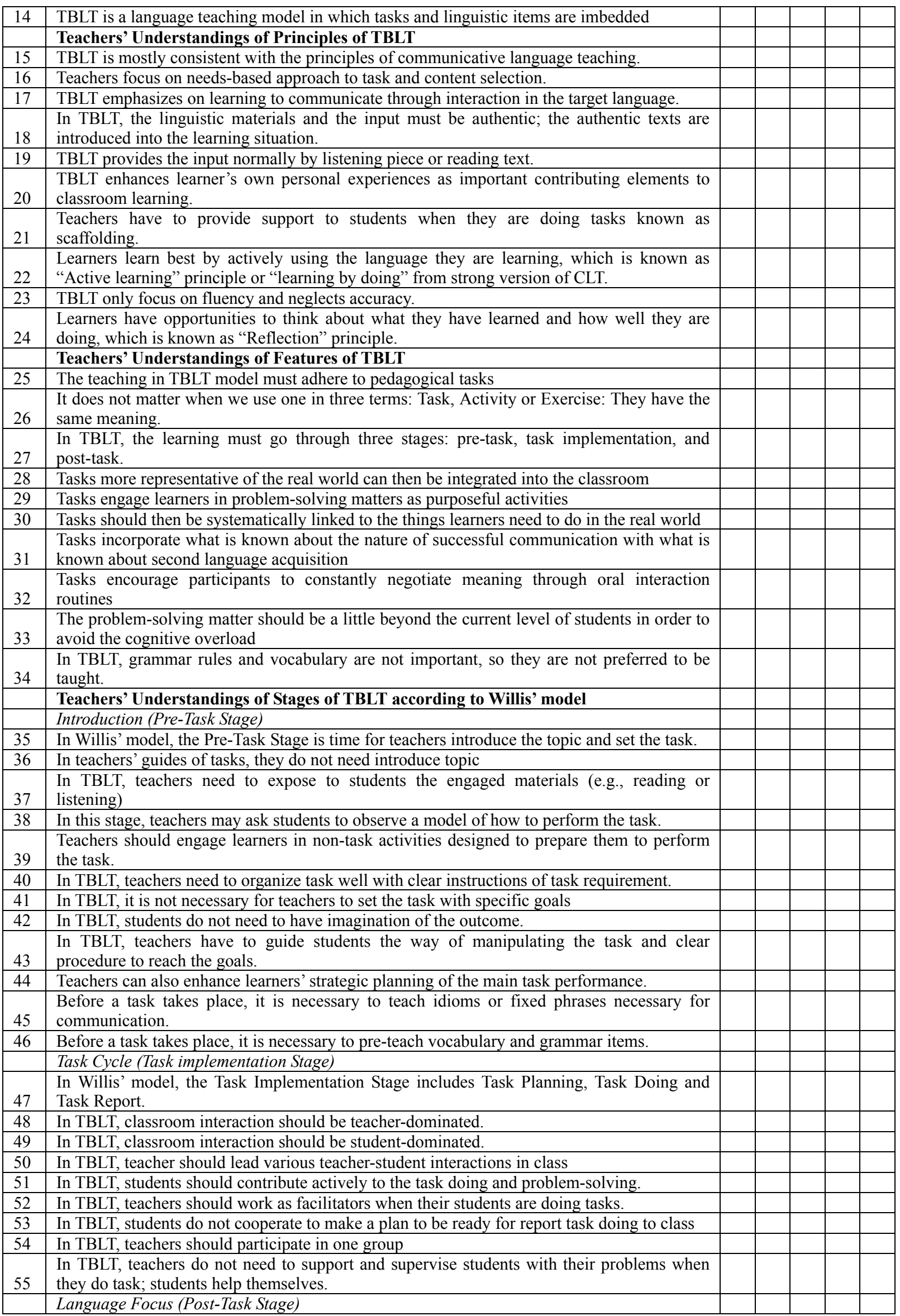




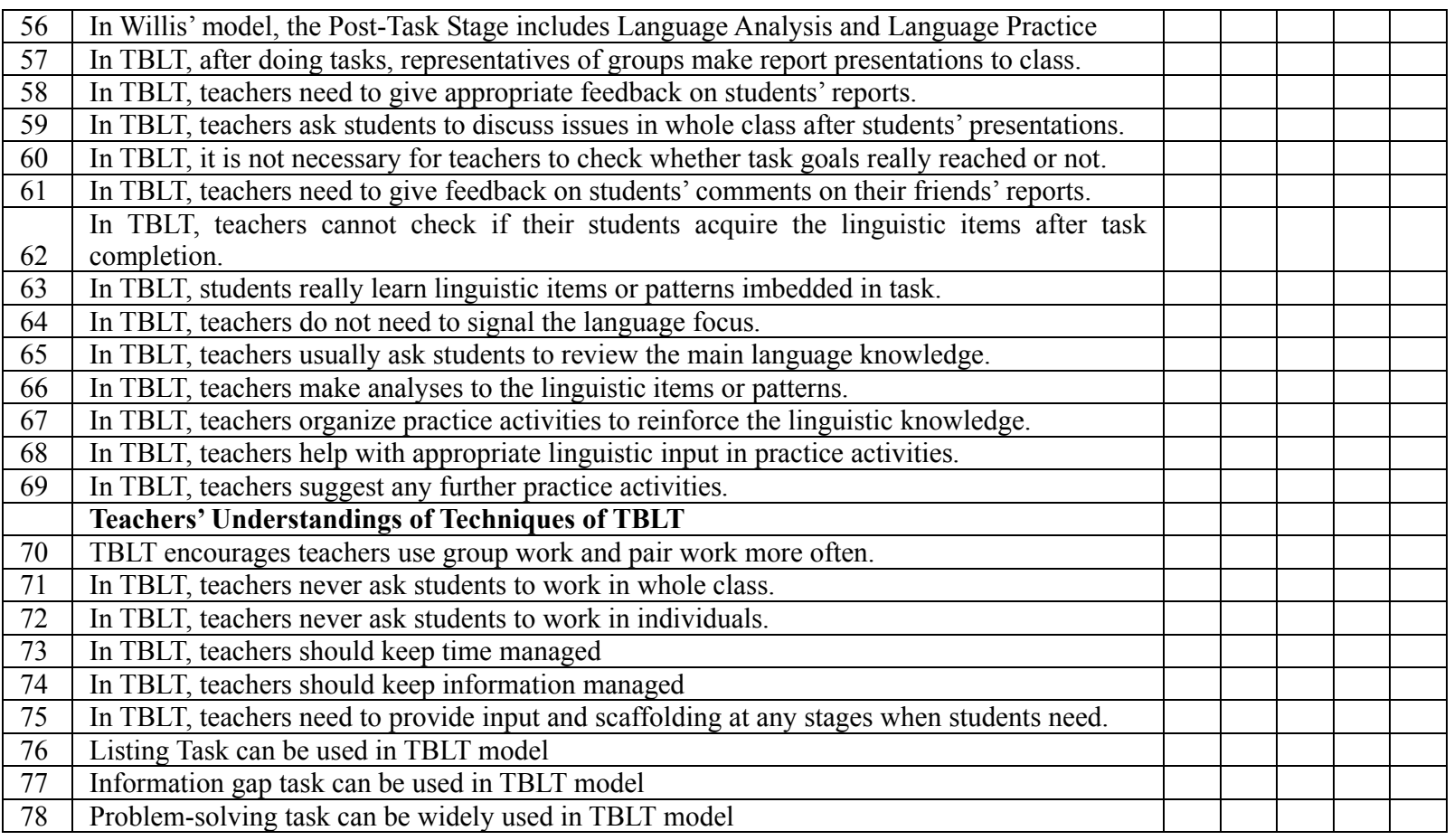

Is it easy for you to understand all statements in the questionnaire? ..........................

Are you completely confident with all choices?

If you have any reluctant/hesitated choice, please mark the statements/items

If you need to specify any reasons for the extreme scale choice of any items, please write down here

\section{SECTION 3: Teachers' beliefs of textbooks}

Please state your thought with each indicator/statement below according to five point Likert Scale from the lowest agreement extreme (Strongly disbelieve) to the highest agreement extreme (Strongly believe):
Strongly disbelieve Disbelieve
Slightly believe
Believe
Strongly believe

\begin{tabular}{|l|l|l|l|l|}
\hline 1 & 2 & 3 & 4 & 5 \\
\hline
\end{tabular}

\section{Survey Questionnaire of Teachers' beliefs of textbooks $(\mathbf{N}=)$}

\begin{tabular}{|c|c|c|c|c|c|c|}
\hline \multirow{2}{*}{$\begin{array}{l}\mathbf{N} \\
\mathbf{0}\end{array}$} & \multirow{2}{*}{ Indicators/Statements } & \multicolumn{5}{|c|}{ Scale } \\
\hline & & 1 & 2 & 3 & 4 & 5 \\
\hline & Teachers' Beliefs of the Textbook Objectives & & & & & \\
\hline 1 & The goals of the textbooks are clear and understandable to me. & & & & & \\
\hline 2 & The goals of the textbooks are suitable and reachable to students in my school. & & & & & \\
\hline 3 & Those goals can be met by the implementation of textbooks and teaching materials. & & & & & \\
\hline 4 & The objectives of each section and lesson are clear enough and reachable. & & & & & \\
\hline \multirow[t]{3}{*}{5} & Knowing the objectives of textbooks and lessons helps us more confident in teaching routine. & & & & & \\
\hline & Teachers' Beliefs of the Content of the Textbooks & & & & & \\
\hline & $\begin{array}{l}\text { Teachers' Beliefs of the Suitability of the Content of Textbooks to the Teaching and Teachers' } \\
\text { Background }\end{array}$ & & & & & \\
\hline 6 & The textbooks' content is really effective to my teaching. & & & & & \\
\hline 7 & I and my colleagues like using these textbooks more than former ones. & & & & & \\
\hline 8 & The textbooks' content helps me and my colleagues spend less time preparing the lesson. & & & & & \\
\hline 9 & The teacher's books are well-designed, so I always follow it closely. & & & & & \\
\hline 10 & $\begin{array}{l}\text { The textbooks' content allows me to easily re-design tasks and activities according to my } \\
\text { students' level of English, so I can sometimes use other materials to supplement my teaching. }\end{array}$ & & & & & \\
\hline 11 & The textbooks' content provides adequate practice in vocabulary and grammar. & & & & & \\
\hline 12 & $\begin{array}{l}\text { Focus on forms is not the target of this kind of textbooks, so I spend less time explaining } \\
\text { grammar rules. }\end{array}$ & & & & & \\
\hline
\end{tabular}




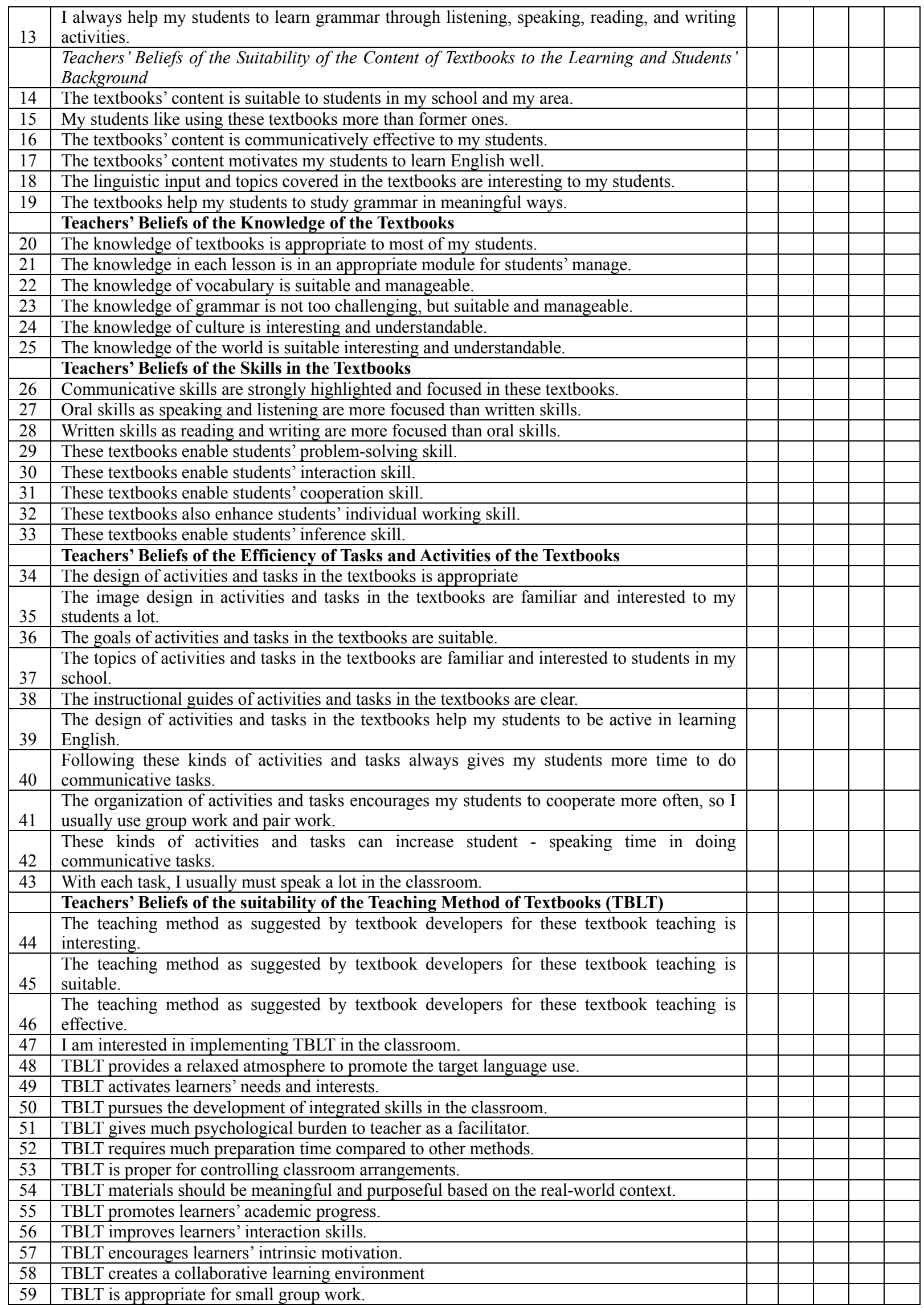

(Note: Numbers of statements are adapted from Le Van Canh, 2007) 
Is it easy for you to understand all statements in the questionnaire?

Are you completely confident with all choices?

If you have any reluctant/hesitated choice, please mark the statements

If you need to specify any reasons for the extreme scale choice of any items, please write down here

\section{Appendix B: Semi-structured Interview Questions}

\section{Interview Question about Teachers' Perceptions of TBLT}

1. How do you understand by a task-based approach to teaching?

(Probing indicators: terminology, approaches, framework, stages, principles, techniques...)

2. Can you give an example of tasks?

(Probing indicators: Maybe tasks you have carried out with your students...)

3. Do you often employ tasks in your teaching? If so, what kinds, and how effective are they?

(Probing indicators: communicative task, problem-solving task, gap-information task, language practice task...)

4. Do you know the teaching instruction model in you textbooks is in TBLT?

(Probing indicators: Model of language teaching? How many models do you know? What is teaching model of CLT? ...)

5. What do you think are positive elements and negative elements of task-based teaching?

6. How many stages do you usually go through when you teach according to TBLT? What do you do in the post task stage of task cycle?

(Probing indicators: Remember the lessons you have taught; the design in textbooks...)

7. What are the main issues in classroom implementation of tasks?

(Probing indicators: Task's goals, task procedure, task doing...)

8. How do you see the relationship between task-based teaching and grammar? How do you help my students to learn grammar?

9. What do you think makes task-based teaching different from other teaching approaches?

(Probing indicators: approaches, instruction model, stages, principles, techniques...)

10. How culturally suitable do you think task-based teaching is for your school or students?

(Probing indicators: social awareness of learning importance, social learning need, social customs affecting the learning need, students' need, students' proficiency, students' learning strategy, students' habits.....)

11. How well do you think teachers in your school understand task-based teaching?

(Probing indicators: terminology, approaches, framework, stages, principles, techniques...)

12. What do you think are the main factors facilitating or inhibiting the implementation of task-based approaches in your teaching context?

(Probing indicators: teacher's perception of TBLT, T's negative attitudes, Students' background/proficiency, Facility, Economy....)

13. Why did you report in your questionnaire that. ?

\section{Interview Question about Teachers' Beliefs about Textbooks}

1. What do you think are the most important elements in a textbook of English?

2. What do you think about the textbook objectives? How suitable are they in teaching?

3. What do you think about the content of the textbooks? How useful are they in teaching?

4. What do you think about the knowledge of the textbooks? How do you decide what you will teach? 
5. What kinds of skills do you think the textbooks can develop for students?

6. How effective are tasks and activities in the textbooks? To what extent are they based on your students' needs?

7. What is your attitude toward the teaching method of textbooks (TBLT)? How suitable is it to your teaching?

8. What changes would you like to see in the textbooks?

9. What do you think is your colleague's attitude toward the textbooks?

\section{Appendix C: CHECKLIST FOR OBSERVATION}

\section{Pre-observation Information}

Observer: Nguyen Viet Hung

Teacher Name

Sex:

School:

Class:

Date of teaching:

Class size:

Unit:.

Lesson:

\section{Some Pre-observation Structured Interview Questions for Teacher}

1. What are your overall objectives/goals for this lesson?

2. Are you targeting any particular teaching approach, teaching method, or any lesson designing guide books?

3. What linguistic knowledge do you intend to construct your students?

4. What tasks are you setting for your students?

5. What procedure are you giving to your students to achieve your instructional goals?

6. What activities will your students be doing?

Detailed Observation Checklist of Reflective teaching in second language classrooms

\begin{tabular}{|c|c|c|}
\hline No. & Indicators/Items & $\begin{array}{l}\text { Presence } \\
\text { (Yes) }\end{array}$ \\
\hline & Homework checking & \\
\hline & Warm-up activity & \\
\hline \multicolumn{3}{|c|}{ Task 1: } \\
\hline \multicolumn{3}{|c|}{ Pre-task } \\
\hline 1 & Does teacher signal the approach to teach? & \\
\hline 2 & Does teacher introduce topic? & \\
\hline 3 & Does teacher expose to students the engaged materials (reading or listening)? & \\
\hline 4 & Is the material authentic? & \\
\hline 5 & Does teacher organize task well with clear instructions of task requirement? & \\
\hline 6 & Does teacher set the task with clear and specific goals? & \\
\hline 7 & Does teacher guide students the way of manipulating the task and clear procedure to reach the goals? & \\
\hline 8 & Does teacher show students enough imagination of the outcome? & \\
\hline 9 & Does teacher provide input and scaffolding? & \\
\hline \multicolumn{3}{|c|}{ Task Cycle } \\
\hline 10 & Is there teacher-dominated Classroom interaction? & \\
\hline 11 & Is there student-dominated Classroom interaction? & \\
\hline 12 & Does teacher signal the doing task phase clearly? & \\
\hline 13 & Does teacher ask students cooperate in pairs? & \\
\hline 14 & $\begin{array}{l}\text { Does teacher ask students cooperate in groups? } \\
\text { (group number: ---------) }\end{array}$ & \\
\hline 15 & Do students contribute actively to the task doing? & \\
\hline 16 & Does teacher facilitate the communicative activity with in time input or scaffolding? & \\
\hline 17 & 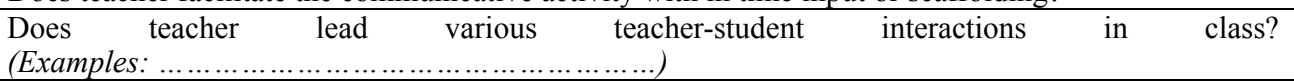 & \\
\hline 18 & Do students cooperate to make a plan to be ready for report task doing to class? & \\
\hline 19 & Does teacher support and supervise students with their problems when they do task? & \\
\hline 20 & Does teacher participate in any group? & \\
\hline 21 & Teacher does time management? & \\
\hline
\end{tabular}




\begin{tabular}{|l|l|l|}
\hline 22 & Teacher does information management? & \\
\hline 23 & Do representatives of groups make report presentations to class? & \\
\hline 24 & Does teacher give appropriate feedback on students' report? & \\
\hline 25 & Does teacher ask students to discuss issues in whole class after students' presentations? & \\
\hline 26 & Do the task goals really reached? & \\
\hline 27 & Does teacher manage whether students complete the task goals and get desirable result or not? & \\
\hline 28 & Does teacher give appropriate feedback on students' comments? & \\
\hline Post-task & & \\
\hline 29 & Did students really acquire from the lesson the linguistic items or patterns imbedded in task? & \\
\hline 30 & Does teacher signal the language focus? & \\
\hline 31 & Does teacher ask students to review the main language knowledge? & \\
\hline 32 & Does teacher make any analysis to the linguistic items or patterns? & \\
\hline 33 & Does teacher organize practice activities to reinforce the linguistic knowledge? & \\
\hline 34 & Does teacher help with appropriate linguistic input? & \\
\hline 35 & Does teacher suggest any further practice activities? & \\
\hline
\end{tabular}

\section{Some Possible Post-observation/Follow-up Unstructured Interview Questions for Teacher}

1. Were you able to accomplish your goals? What was the main accomplishment of the lesson?

2. Which parts of the lesson were most successful? Why do you think that?

3. Which parts of the lesson were least successful? Why do you think that?

4. Were you able to teach by the philosophy of teaching that you have targeted?

5 . What teaching procedures did you use? Why did you choose those?

6. How effective were the teaching materials?

7. Could you construct your students the target linguistics knowledge? What do you think students really learned from the lesson?

8. Were you successful in setting tasks for your students?

9. Were you successful in supporting your students with their task doing? What techniques did you use? Why did you do that?

10. What kind of teacher-student interaction do you think occurred most?

11. What grouping arrangements did you use (individuals, pairs or groups)? Why did you do that?

12. Did students contribute actively to the lesson? What did they like most about the lesson?

13. How did you respond to different students' needs? What roles do you think you could play to help your students study?

14. Why did you do the technique. in your class teaching?

15. Did you have any problems with the lesson? Were students challenged by the lesson?

16. Did you depart from your lesson plan? If so, why? Did the change make things better or worse?

17. Would you teach the lesson differently if you taught it again? 